\title{
El dermatólogo ríe
}

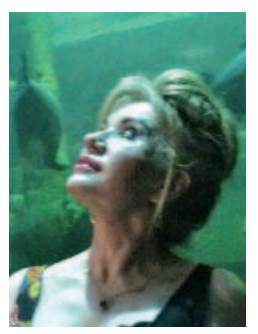

Aurora Guerra Tapia Jefa de Sección de Dermatología. Hospital Universitario 12 de Octubre. Madrid. Profesora titular de Dermatología. Universidad Complutense de Madrid.
Quítame el pan si quieres.

Quítame el aire.

Pero no me quites tu risa.

Pablo Neruda

(1904-1973)
Hace tiempo que dimití irrevocablemente del encargo de vivir con amargura, de la responsabilidad de custodiar el rencor, de la obligación de lanzar críticas malignas o del contrato de atesorar incomprensión. Mi apetito de felicidad es resueltamente proactivo. Y en esa decisión, una protagonista por excelencia es la risa.

Y aunque este propósito nace de mis propias fuentes, puedo asegurar que no invento nada. Ya en el siglo I antes de Cristo, Publilius Syrius (85 a.C. 43 a.C.), escritor romano afamado por sus sentencias, afirmó: Deos ridere credo, cum felix vocat. Esto es, «creo que hasta un dios ríe cuando un hombre feliz le invoca».

La risa.

Ese gesto ruidoso que cambia el rostro y convulsiona el cuerpo. Esa mueca incontenible, vehemente, feroz, a la que a menudo se le atribuyen poderes tan audaces, que son capaces de hacernos «morir de risa», "mondarnos de risa", "partirnos de risa», «reventar de risa», «desternillarnos de risa», «descoyuntarnos de risa», e incluso, «mearnos de risa».

Dicen los libros de fisiología que cuando reímos, se contraen simultá- neamente quince músculos de la cara, surgen respiraciones espasmódicas y se emiten sonidos entrecortados irreprimibles.

Explican los escritos de neurología que al reír, se liberan desde la glándula pituitaria del cerebro, neurotransmisores del bienestar psicológico que arrinconan el estrés, evaporan la ansiedad y mejoran la salud emocional.

Y yo añadiría, a fuer de resultar atrevida, que también se parece a una satisfactoria actividad sexual. ¿No es cierto acaso, que la risa es incontrolable y placentera, libera endorfinas, produce una descarga física seguida de bienestar y deja una deliciosa sensación de agotamiento, cual si de un orgasmo se tratara?

Por otra parte, la risa tiene un carácter democrático indudable: no hace distinción de edad, de clase social, de cultura, de creencias o de género. Es igualitaria y conciliadora (fig. 1).

Así pues, hay que reír. Si somos inteligentes, debemos reír. Ya lo dijo Marco Valerio Marcial, el poeta nacido en Bílbilis, actual Calatayud, en el siglo I, cuando escribió en sus Epigramas (fig. 2): «Si eres sabio, ríe». 


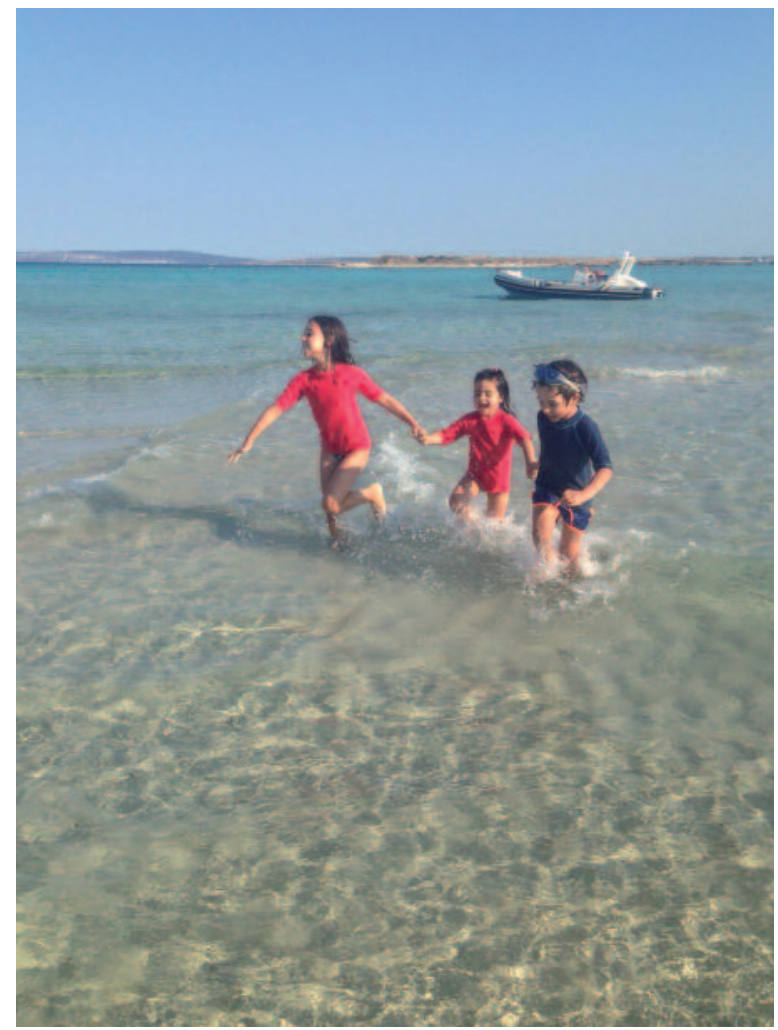

Figura 1. Sofía, Claudia y Alfonso. La risa de los niños, un ejemplo de felicidad.

Muy de acuerdo con su opinión, yo creo que solo el individuo inteligente es capaz de reír en el momento oportuno: hay que captar las dobles lecturas, las sátiras subyacentes, las bromas disimuladas, el fulgor divertido de las situaciones comprometidas. Un público impávido ante un hecho ingenioso no demuestra profundidad, sino estulticia.

Apuntan además los sabios de la psicología que el recorrido entre la acción de reír y la sensación de bienestar es bidireccional. Podemos reír porque estamos alegres, o podemos reír intencionadamente, para poder estar alegres.

Así pues hay que reír.

Pero, ¿encuentra suficiente incitación a la risa el dermatólogo en el trabajo diario?

Difícil, pero posible. Siempre habrá un motivo si lo buscamos. Una anécdota casual, una coinci-

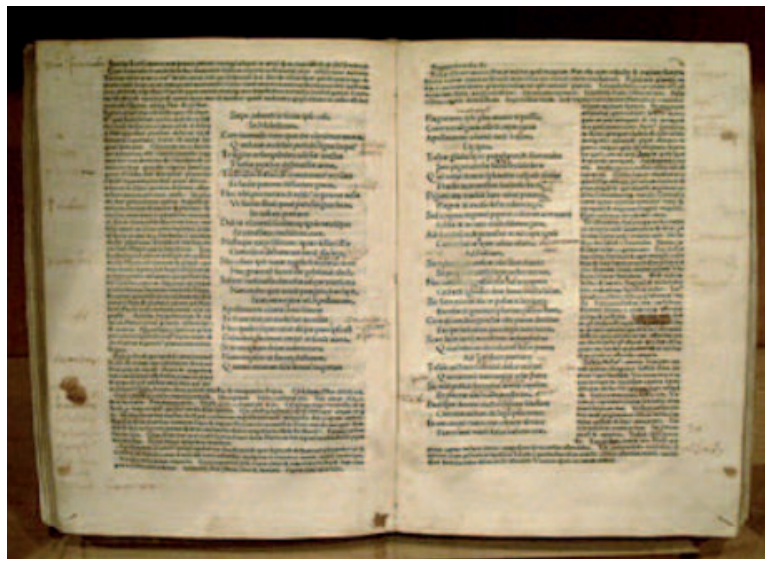

Figura 2. Incunable de los Epigramas de Marcial, editado en 1490 en Milán por Udalricus Scinzenzeler. Archivo del Gobierno de Aragón.

dencia amable o simplemente el deseo compartido con el paciente de ser feliz. Y por una vez, y sin que sirva de precedente, favorezcamos el contagio. Formemos una cadena de sonrisas que nos aprisione en una cárcel adictiva y dulce, de la que no querremos escapar.

Seguramente, reír también es bueno para la piel. Se lo dice una dermatóloga.

\section{BIBLIOGRAFÍA RECOMENDADA}

González-Guerra E. Carta de una MIR. Gac Med. 2004;53 (II):5.

González-Guerra E. De guardia. En: Guerra-Tapia A, ed. Anécdotas en Dermatología. Madrid: EDIMSA; 2006. p. 40-1.

González-Guerra E. Las vitaminas están en la piel. En: GuerraTapia A, ed. Anécdotas en Dermatología 2. Madrid: EDIMSA; 2010. p. 79-81.

González-Guerra E. La sala de espera. En: Anécdotas médicas en prosa y en verso. Madrid: ASEMEYA; 2007.

González-Guerra E. Manual del 28. En: Guerra-Tapia A, ed. Anécdotas en Dermatología. Madrid: EDIMSA; 2006. p. 235.

González-Guerra E. ¿Qué he hecho yo durante estos seis años? [Internet] Asociación Española de Mujeres Dermatólogas (DAME). (Society of Women Dermatologist Spanish). [Consultado: 6 de julio de 2016]: Disponible en: http://www.mujeresdermatologas.com/contenido.php?padre=1 $5|35| 58 \& \mid D C o n t e n i d o=58$

González-Guerra E. The art of Laughter. Actas Dermosifiliogr. 2008;99:79-80.

Guerra-Tapia A. Anécdotas en Dermatología. Madrid: EDIMSA; 2006.

Guerra-Tapia A. Anécdotas en Dermatología 2. Madrid: EDIMSA; 2010. 